\title{
НОВЫЕ КНИГИ
}

УДК 304.2

\section{РЕЦЕНЗИЯ НА МОНОГРАФИЮ О.В. ВАСИЛЬЕВОЙ «ЭТНИЧНОСТЬ И ОБЩЕСТВО В РЕСПУБЛИКЕ САХА (ЯКУТИЯ): СОЦИОЛОГИЧЕСКИЙ АНАЛИЗ» (ЯКУТСК, 2020)}

\author{
Г.Ф. Габдрахманова \\ Институт истории им. Ш. Марджани \\ Академии наук Республики Татарстан \\ Казань, Российская Федерация \\ medi54375@mail.ru
}

Статья посвящена анализу новый книги - монографии О.В. Васильевой «Этничность и общество в Республике Саха (Якутия): социологический анализ», опубликованной в 2020 г. в Якутске. Ее достоинством является новый оригинальный подход к изучению процесса конструирования этничности в условиях развития капиталистических отношений и современных глобальных экономических потоков. Рецензент приводит некоторые параллели в социальном развитии якутов и татар на различных исторических этапах. Это появление буржуазии и политических организаций в начале XX в., специфическое маркирование под влиянием конституционных актов Советской республики и переписных кампаний постсоветского времени, «приобретение республик» в условиях советской практики национального районирования территорий и т.д. Все такие факты высвечивают как много общего было среди народов тюркского мира российской империи, СССР и РФ. Монография О.В. Васильевой стимулирует к новым изысканиям в области социальных аспектов функционирования этничности тюркского мира.

Ключевые слова: якуты, татары, этничность, социальные аспекты, капитализм

Для цитирования: Габдрахманова Г.Ф. Рецензия на монографию О.В. Васильевой «Этничность и общество в Республике Саха (Якутия): социологический анализ» (Якутск, 2020) // Историческая этнология. 2021. Т. 6, № 1. C. 177-182. https://doi.org/10.22378/he.2021-6-1.177-182

Рецензируемая монография посвящена вопросу маркирования социального пространства этническими категориями в условиях формирования капиталистических отношений. Несмотря на сосредоточенность автора на отдельном регионе - Республике Саха (Якутия), указанная проблема имеет большое значение для этнологической науки. Оно проявляется в том, что 
приводимый в книге научно-аналитический материал показывает, как много общего у представителей разных национальностей Российской империи, СССР и РФ, и к каким близким результатам в их развитии приводили общественные трансформации.

Получение знаний о сути и логике социальной стороны этничности возможно в рамках разнообразных методологических приемов. В современной отечественной академической среде весьма популярна конструктивисткая и полипарадигмальная парадигма. Исследователи сосредотачиваются на вопроcax разнообразных идентичностей этнических групп, проблемах воспроизводства этнического самосознания и межэтнических отношений. Но вопрос о том, как этничность и созданные социальными инженерами продукты вписываются в глобальные экономические потоки, остается пока мало разработанным, хотя в региональных научных школах за последние два с половиной десятка лет накоплен богатый исторический, этнологический и этносоциологический материал. Монография О.В. Васильевой, по нашему мнению, выводит на обобщающие фундаментальные выводы. В качестве их иллюстрации приведем несколько параллелей в развитии якутов и татар.

XIX век - время формирования капиталистических отношений и буржуазии в среде многих народов Российской империи. У них начинают развиваться товарно-денежные и социально-классовые отношения. Появившиеся национальные элиты стремятся выйти не только на арену экономических, но политических и социальных процессов. Эту ситуацию стимулировала практика производства этнического неравенства, в том числе в отношении формирующейся якутской буржуазии (Васильева 2020: 20) и татар. В условиях дискриминационной имперской политики у последних на рубеже $\mathrm{XIX}-\mathrm{XX}$ вв. появляется мощный отряд буржуазии, активно занимавшийся строительством мечетей, благотворительностью для поддержки малоимущих, спонсированием печати татарских газет и журналов, театрального и художественного искусства татарского народа. И если у якутов в начале XX в. была осуществлена первая попытка создания политической организации по этническому принципу - «Союз якутов», которая объединила, прежде всего, тойонат, крупных торговцев, домовладельцев и интеллигенцию - наиболее образованную часть общества (Васильева 2020: 21), то у татар в таком качестве выступил политический кружок, организованный в 1895 году группой учащихся русско-татарской учительской школы в Казани (Усманова: 75). Одинаковым в то время являлось и стремление якутов и татар к членству в Государственной Думе, а также социально-экономические характеристики национальных элит. Так, у якутов формировалась «элита, построившая свой капитал на торговле и транспортных услугах. Происходит дальнейшая интеграция якутов в имперское социокультурное пространство, в т.ч. через систему образования» (Васильева 2020: 20). Все это наблюдалось и у татар, осваивавших в это время русский язык и рынки Средней Азии и казахстанских степей. 
Габдрахманова Г.Ф. Рецензия на монографию О.В. Васильевой «Этничность и общество в Республике Саха (Якутия): социологический анализ»

Поднятая О.В. Васильевой проблема развития этничности в условиях капиталистических отношений при ее выведении на сравнительный уровень, безусловно, требует учета социально-экономических и этнокультурных специфик нерусских народов Российской империи. Климатические условия, тип традиционного хозяйствования, религия - все это задавало разнообразные модели жизнедеятельности народов страны, но которые, тем не менее, судя по тексту рецензируемой монографии, вписывались в общую логику этничности. Ее определяли первые конституционные акты Советской республики, заложившие «основание современных представлений об этнической структуре общества, имевших далеко идущие последствия для институциональной архитектуры, идеологии и бытового самосознания населения будущего СССР» (Васильева 2020: 22).

Трудно не согласиться с автором в том, что последовавшие в первые годы советской власти национальное районирование территорий (Васильева 2020: 23) и переписные кампании политически закрепили этническое маркирование социального пространства СССР. Такие спорадически возникающие обращения этнических предпринимателей к этничности как к основе для категоризации населения фиксируются и в других исторических условиях. Так, О.В. Васильева весьма любопытно описывает процесс приписывания и навязывания этнических маркеров народам современной Республике Саха (Якутия). Причем его возникновение ею убедительно доказывается причинами экономических интересов Российской империи и представлений ее власти об эволюционном развитии инородческих народов. Наши наблюдения за процессом возникновения научных и общественных дискуссий об единстве/дифференциации татарского народа, появившихся в преддверии последних двух Всероссийских переписей населения и ожидаемой в сентябре 2021 г. очередной переписи, расширяют список социальных инженеров этничности за счет включения в него и других пассионариев, стремящихся завоевать на кампании разнообразные дивиденды.

Последовавшая после районирования территории Российской империи активная индустриализация СССР, в том числе республик, обретение ими нового статуса в начале 1990-х гг. простимулировали национальную мобилизацию и рост национализма (по Э.Геллнеру) у многих народов страны. Последовало стремление российской политической элиты к формированию общероссийской идентичности. О.В. Васильева дает ей следующую оценку: «Несмотря на то, что термин «нация» в новом гражданском и политическом значении, который пытались внедрить в общественное сознание, так и не нашел понимания» (Васильева О.В. Этничность и общество в Республике Саха (Якутия): социологический анализ. Якутск, 2020. С. 167). Далее автор спрашивает: «Но можно ли это объяснить только тем, что «этничность, формируемая неравенством, оказалась настолько глубоко укоренена в сознании граждан, институтах общества, что путем простой смены значений слов, которая происходит сейчас в сфере национальной политики, изменить ее невозможно». Может быть, следуя методологической логике автора, здесь стоит 
поразмышлять о роли замедленных постиндустриальных преобразований в российском обществе, которые тормозят формирование национально-гражданской идентичности в российском обществе?

Перспективное расширение рамок поставленной автором проблемы видится в пространственном и территориальном аспекте. Обозначая основания методологической рамки исследования, О.В. Васильева указывает на то, что «формирование российского государства ... происходило в качестве одной из полупериферийных стран, а ее особенностью стало соединение периферийного развития капитализма с формированием сильного самостоятельного государства, ставшего важным элементом в системе европейских империй» (Васильева 2020: 6). В этом проглядывается некоторая обуженность исследования этносоциальных процессов у народов России. Для Северной Евразии, Дальнего Востока, Центральной Азии и казахстанских степей Российская империя являлась частью другой, неевропейской мир-системы с собственной, культурно обусловленной логикой развития капиталистических отношений. В их воспроизводстве российские народы на разных этапах выполняли посредническую роль в продвижении интересов государства на Восток, Азию и Арктику, участвовали в расширении его границ, развитии экономики страны и национальной буржуазии за счет ресурсов сопредельных северных, восточных и южных территорий. Был бы интересен авторский взгляд и на процесс огосударствления этничности субъектами РФ, упомянутый лишь вскользь (Васильева 2020: 167). Для выведения интересующих нас параллелей в развитии разных народов страны было бы интересно узнать, как Республика Саха (Якутия) строила собственную политику этнической идентичности в отношении якутов и как она менялась под влиянием интересов федерального Центра, встраивалась в предлагаемые им акценты общегосударственной национальной политики.

Связанным с обозначенным аспектом выступает актуализируемый автором вопрос о локальных идентичностях. О.В. Васильева отмечает, «что в языковой картине мира современных якутов (саха) произошел существенный сдвиг в представлениях о границах родной земли, которая сегодня чаще ассоциируется с территорией существующих административных улусов (районов), а также Республики Саха в целом» (Васильева 2020: 77). Жаль, что в работе этот сюжет не получил объяснения. По нашим наблюдениям, локальные идентичности - весьма распространенное явление среди тюркских народов. Среди алтайцев сохраняются устойчивые и массовые представления о сёоках (родах). У татар память о родах и местах рода не сохранилась совсем, хотя очень велика связь с деревней, откуда происходит семья, родственный круг.

Обозначенные дискуссионные вопросы - это темы для будущих сравнительных исследований. Представляется, что монография О.В. Васильевой дает для них хороший импульс. Исследователь задал много интересных вопросов, стимулирующих к новым научным изысканиям. Книга 
Габдрахманова Г.Ф. Рецензия на монографию О.В. Васильевой «Этничность и общество в Республике Саха (Якутия): социологический анализ»

содержит достаточно новый, не очень популярный в российской науке подход, но весьма оригинальный, а порой и смелый, нестандартный взгляд автора на некоторые устоявшиеся представления об этничности. Поэтому рецензируемый труд заслуживает пристального внимания со стороны представителей этнологической науки.

\title{
НАУЧНАЯ ЛИТЕРАТУРА
}

Васильева О.В. Этничность и общество в Республике Саха (Якутия): социологический анализ. Якутск, 2020. http://igi.ysn.ru/files/publicasii/etichnost.pdf (Дата обращения 18.01.2021).

Усманова Д. Контакты татар с общероссийскими политическими партиями и образование первых мусульманских (татарских) политических организаций // История татар с древнейших времен. Т. VII. Казань, 2013. С. 75-78.

Сведения об авторе: Габдрахманова Гульнара Фаатовна - доктор социологических наук, доцент, заведующая отделом этнологических исследований Института истории им. Ш.Марджани Академии наук Республики Татарстан (420111, ул. Батурина, 7А, Казань, Российская Федерация); medi54375@mail.ru

Поступила 20.01.2021

Принята к публикации 22.03.2021

Опубликована 21.04.2021

\section{REVIEW OF THE MONOGRAPH BY O.V. VASILYEVA \\ "ETHNICITY AND SOCIETY IN THE REPUBLIC OF SAKHA (YAKUTIA): SOCIOLOGICAL ANALYSIS" (YAKUTSK, 2020)}

\author{
G.F. Gabdrakhmanova \\ Marjani Institute of History of the Tatarstan Academy of Sciences \\ Kazan, Russian Federation \\ medi54375@mail.ru
}

The article is devoted to the analysis of a new book - a monograph by O.V. Vasilyeva "Ethnicity and Society in the Republic of Sakha (Yakutia): Sociological Analysis", published in 2020 in Yakutsk. Its advantage is a new original approach to studying the process of constructing ethnicity in the context of the development of capitalist relations and modern global economic flows. The reviewer gives some parallels in the social development of the Yakuts and Tatars at different historical stages. This is the emergence of the bourgeoisie and political organizations at the beginning of the 20th century, specific labeling under the influence of the Soviet Republic constitutional acts and post-Soviet census campaigns, the "acquisition of republics" in the conditions of the Soviet practice of national zoning of territories, etc. All such facts highlight how much 
the peoples of the Turkic world of the Russian Empire, the USSR, and the Russian Federation had in common. The monograph by O.V. Vasi-lyeva encourages new research in the field of social aspects of the the Turkic world ethnicity functioning.

Keywords: Yakuts, Tatars, ethnicity, social aspects, capitalism

For citation: Gabdrakhmanova G.F Retsenziya na monografiyu O.V. Vasil'evoy «Etnichnost' i obshchestvo v Respublike Sakha (Yakutiya): sotsiologicheskiy analiz» (Yakutsk, 2020) [Review of the monograph by O.V. Vasilyeva "Ethnicity and Society in the Republic of Sakha (Yakutia): Sociological Analysis" (Yakutsk, 2020)]. Istoricheskaya etnologiya, 2021, vol. 6, no. 1, pp. 177-182. https://doi.org/10.22378 /he.2021-6-1.177-182

\section{REFERENCES}

Usmanova D. Kontakty tatar s obshcherossiyskimi politicheskimi partiyami i obra-zovanie pervykh musul'manskikh (tatarskikh) politicheskikh organizatsiy [Contacts of Tatars with all-Russian Political Parties and the Formation of the First Muslim (Tatar) Political Organizations]. Istoriya tatar s drevneyshikh vremen. T. VII. Kazan, 2013. P. 75-78. (In Russian)

Vasil'eva O.V. Etnichnost' $i$ obshchestvo v Respublike Sakha (Yakutiya): sotsiologicheskiy analiz [Ethnicity and Society in the Republic of Sakha (Yakutia): Sociological Analysis]. Yakutsk, 2020. (In Russian) Available at: http://igi.ysn.ru/files /publicasii/etichnost.pdf (Accessed 18.01.2021).

About the author: Gulnara F. Gabdrakhmanova, Doctor Sc. (Sociology), Associate Professor, Head of the Department of Ethnological Research, Marjani Institute of History of the Tatarstan Academy of Sciences (7A Baturin St., Kazan 420111, Russian Federation); medi54375@mail.ru 